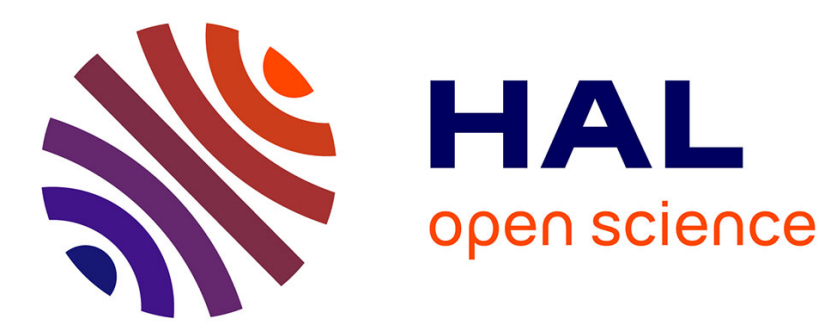

\title{
(Ba6O)(ReN3)2: Synthesis, crystal structure and physical properties
}

Carsten Schmidt, Robert Dinnebier, Martin Jansen

\section{To cite this version:}

Carsten Schmidt, Robert Dinnebier, Martin Jansen. (Ba6O)(ReN3)2: Synthesis, crystal structure and physical properties. Journal of Inorganic and General Chemistry / Zeitschrift für anorganische und allgemeine Chemie, 2010, 636 (15), pp.2529. 10.1002/zaac.201000293 . hal-00599886

\section{HAL Id: hal-00599886 \\ https://hal.science/hal-00599886}

Submitted on 11 Jun 2011

HAL is a multi-disciplinary open access archive for the deposit and dissemination of scientific research documents, whether they are published or not. The documents may come from teaching and research institutions in France or abroad, or from public or private research centers.
L'archive ouverte pluridisciplinaire HAL, est destinée au dépôt et à la diffusion de documents scientifiques de niveau recherche, publiés ou non, émanant des établissements d'enseignement et de recherche français ou étrangers, des laboratoires publics ou privés. 


\section{$\left(\mathrm{Ba}_{6} \mathrm{O}\right)\left(\mathrm{ReN}_{3}\right)_{2}:$ Synthesis, crystal structure and physical properties}

\begin{tabular}{|c|c|}
\hline Journal: & Zeitschrift für Anorganische und Allgemeine Chemie \\
\hline Manuscript ID: & zaac.201000293.R1 \\
\hline Wiley - Manuscript type: & Communication \\
\hline $\begin{array}{r}\text { Date Submitted by the } \\
\text { Author: }\end{array}$ & 30-Jul-2010 \\
\hline Complete List of Authors: & $\begin{array}{l}\text { Schmidt, Carsten; MPI für Festkörperforschung, Chemie III } \\
\text { Dinnebier, Robert; MPI für Festkörperforschung, Röntgenographie } \\
\text { Jansen, Martin; MPI für Festkörperforschung }\end{array}$ \\
\hline Keywords: & Nitrides, Rhenium, Crystal structure, X-ray powder diffraction \\
\hline
\end{tabular}

\section{SCHOLARONE ${ }^{m}$ \\ Manuscripts}




\section{Short Communication}

\section{Introduction}

Recently, we reported on the synthesis and characterization of $\left(\mathrm{Ba}_{6} \mathrm{O}\right)\left(\mathrm{OsN}_{3}\right)_{2}$, the first nitridoosmate [1]. It exhibits the peculiarity of containing oxygen, although its incorporation was (originally) not intended. Obviously, a hypothetic nitridoosmate of composition " $\mathrm{Ba}_{3} \mathrm{OsN}_{3}$ " shows an extreme affinity to oxygen, gettering even traces of oxygen from the flow of purified nitrogen. This phenomenon cannot be understood in terms of structural stability since the by ternary transition metal nitrides widely adopted $\mathrm{Ba}_{3} \mathrm{FeN}_{3}$ type of structure [2] would also provide a well suitable configuration for " $\mathrm{Ba}_{3} \mathrm{OsN}_{3}$ ", as is indicated by the fact that the actual structure of $\left(\mathrm{Ba}_{6} \mathrm{O}\right)\left(\mathrm{OsN}_{3}\right)_{2}$ is closely related to the former. Extensive quantum mechanical calculations have proven electronic effects to rather be responsible. In order to check if such a phenomenon is unique and restricted to osmium only, we have run similar syntheses for the system $\mathrm{Ba} / \mathrm{Re} / \mathrm{N} / \mathrm{O}$, indeed yielding the isostructural rhenate $\left(\mathrm{Ba}_{6} \mathrm{O}\right)\left(\mathrm{ReN}_{3}\right)_{2}$.

\section{Experimental Section}

\section{Synthesis}

Ba metal (purified by sublimation) and Re metal were mixed in a 3:1 ratio and filled in a pre-dried (treated in vacuum at $\mathrm{T}=1000{ }^{\circ} \mathrm{C}$ ) $\mathrm{Ta}$ finger tube. The reactants were heated up to $\mathrm{T}=850{ }^{\circ} \mathrm{C}$ in an atmosphere of nitrogen for $50 \mathrm{~h}$. Nitrogen of quality 4.8 was used and standard drying conditions were applied. After 12, 24 and $36 \mathrm{~h}$, the powder sample was re-ground and analyzed via powder $\mathrm{X}$-ray diffraction. $\mathrm{Ba}_{2} \mathrm{~N}$ was found as intermediate phase. After the repeated treatments, no indications for the presence of Re metal or $\mathrm{Ba}_{2} \mathrm{~N}$ were given. The sample is a microcrystalline black powder

\footnotetext{
* Prof. Dr. Dr. h.c. Martin Jansen

Max-Planck-Institut für Festkörperforschung

Heisenbergstrasse 1, 70569 Stuttgart

Fax: +497116891502

E-mail: M.Jansen@fkf.mpg.de
}

length of $1.94 \AA$, and is planar within the limits of experimental error. The constitution of the anion was confirmed by IR and Raman spectroscopy. The nitride-oxide is stable up to $1000{ }^{\circ} \mathrm{C}$, semiconducting $\left(\sigma=4.57 * 10^{-3} \Omega^{-1} \mathrm{~cm}^{-1}\right.$ at RT), and paramagnetic down to $25 \mathrm{~K}$. A Curie-Weiss analysis resulted in a magnetic moment of $\mu=0.68 \mu_{\mathrm{B}}$ per rhenium atom.

Keywords: Nitrides; Rhenium; Crystal structure; X-ray powder diffraction

which hydrolyzes quickly in moist air.

\section{$X$-ray powder diffraction}

X-ray powder diffraction data of $\left(\mathrm{Ba}_{6} \mathrm{O}\right)\left(\mathrm{ReN}_{3}\right)_{2}$ were collected at room temperature with a Stoe Stadi-P transmission diffractometer (primary beam Johannson-type Ge monochromator for Mo-K $\alpha_{1}$-radiation, linear PSD) with the sample sealed in a glass capillary of $0.3 \mathrm{~mm}$ diameter (Hilgenberg, glass No. 50). The powder pattern was recorded for $20 \mathrm{~h}$ in the range from 2-60 $2 \theta$ with a step width of $0.01^{\circ} 2 \theta$ using a linear position sensitive detector with an opening of approximately $12^{\circ} 2 \theta$. Structure determination and refinement was performed using the program TOPAS Version 3.0 (Bruker AXS, 2007). The peak profiles and precise lattice parameters were determined by a LeBail fit [3] using the fundamental parameter approach of TOPAS [4]. Agreement factors (R-values) of the final Rietveld refinement (Figure 1) are listed in Table 1, the coordinates are given in Table 2, and a selection of intra- and inter-molecular distances and angles is given in Table 3. Further details of the crystal structure investigations are available from the Fachinformationszentrum Karlsruhe, D-76344 Eggenstein-Leopoldshafen (Germany), on quoting the depository number CSD-419636, the name of the authors, and citation of the paper.

\section{Thermal analysis}

Simultaneous DTA/TG/MS (STA 409, Netzsch) was performed on a sample placed in a corundum crucible under flowing argon $(100 \mathrm{ml} / \mathrm{min})$ with a heating rate of $10 \mathrm{~K} / \mathrm{min}$.

\section{Spectroscopy}

Infrared spectroscopy was performed on a FT-IR spectrometer (IFS 113v, Bruker) from $400 \mathrm{~cm}^{-1}$ to $4000 \mathrm{~cm}^{-1}$ with $\mathrm{KBr}$ as the solid matrix. For the Raman experiments the powdered sample was filled in a $1.0 \mathrm{~mm}$ lithiumborate glass capillary (Hilgenberg, glass No 14). The measurement was performed with an excitation line of $632.817 \mathrm{~nm}$ (Labram 010, single grating). The acquisition time was between 5 to $300 \mathrm{sec}$ with a laser power between 0.4 and $0.004 \mathrm{~W}$. 


\section{Electrical conductivity measurement}

Measurements were performed on compacted polycrystalline powder pellets (diameter $5 \mathrm{~mm}$, thickness $0.8 \mathrm{~mm}$, pressed with $920 \mathrm{MPa}$ ) using the standard four-point technique.

\section{Energy-dispersive $X$-ray analysis}

EDX analysis was performed on a XL30 TMP (Philips Electron Optics $\mathrm{GmbH}$ ) equipped with an energy-dispersive detector S-UTW(Li) (EDAX). The powder sample was placed on a sample-holder in a glove-box filled with argon. The sample was attached to the machine via a transfer-chamber, providing inert conditions.

\section{Magnetic measurement}

Magnetic susceptibilities were measured with a MPMS7 SQUID Magnetometer (Quantum design) between 2 and $300 \mathrm{~K}$. Powder samples were filled in Suprasil quartz glass tubes filled with helium. The data were corrected for the magnetization of the empty sample holder, and for the diamagnetic contributions of the constituent ions by fitting the data according to $\chi_{\mathrm{g}}$ (korr) $=\chi_{\mathrm{g}}-\chi_{0} . \chi_{0}$ was obtained by fitting the experimental data $\chi_{\mathrm{g}}=\chi_{0}+\mathrm{C}_{\mathrm{g}} /(\mathrm{T}-\theta)$.

\section{Results and Discussion}

The title compound was synthesized by solid-state reaction from elemental barium and rhenium under flowing nitrogen gas. The detailed mechanism of its formation is unknown, but $\mathrm{Ba}_{2} \mathrm{~N}$ has been proven to be an intermediate which got consumed in the course of repeated grinding and annealing cycles. EDX analysis on the black microcrystalline powder confirmed the Ba:Re ratio of 3:1, and proved the presence of $\mathrm{N}$ and $\mathrm{O}$. The Raman data of the title compound is in good agreement with the data provided for $\mathrm{Na}_{4} \mathrm{ReN}_{3}$ [5]. Our spectrum comprised nearly the same bands but also some additional ones, not mentioned previously [positions in $\mathrm{cm}^{-1}: 184,225,362,427,859,949$, 994]. The strong signal at $949 \mathrm{~cm}^{-1}$ is indicative for Re-N multiple bonds. The IR spectrum showed two strong absorptions at $847 \mathrm{~cm}^{-1}$ and $650 \mathrm{~cm}^{-1}$ (shoulder) which are characteristic for a trigonal-planar $\mathrm{ReN}_{3}$ group. Similar IR spectra have been reported for $\left(\mathrm{Ba}_{6} \mathrm{O}\right)\left(\mathrm{OsN}_{3}\right)_{2}$ [1] and $\mathrm{Ba}_{3} \mathrm{FeN}_{3}$ [2]. No indications for $\mathrm{N}-\mathrm{H}$ or $\mathrm{O}-\mathrm{H}$ vibrations were noticable.

Under argon, the compound is stable up to $\mathrm{T}=1000{ }^{\circ} \mathrm{C}$ (mass loss $<0.5 \%$ ), as seen from TG analysis. Massive decomposition starts at $\mathrm{T}>1050{ }^{\circ} \mathrm{C}$, and up to $\mathrm{T}=1300{ }^{\circ} \mathrm{C}$ a total mass loss of $3.7 \%$ is recorded. $\mathrm{BaO}$, elemental Re, and $\mathrm{Ba}_{2} \mathrm{~N}$ were identified as solid residues by $\mathrm{X}$-ray powder diffraction.

The X-ray powder pattern of the compound (Figure 1) was found to be similar to the one of previously described $\left(\mathrm{Ba}_{6} \mathrm{O}\right)\left(\mathrm{OsN}_{3}\right)_{2}$, and both compounds proved to be isostructural. Relevant data concerning the crystal structure is found in tables 1-3. The structure is sketched in Figure 2. The constitutional building blocks are the trigonal antiprismatic $\mathrm{Ba}_{6} \mathrm{O}$ group and the trigonal planar $\mathrm{ReN}_{3}$ moiety. The $\mathrm{Ba}-\mathrm{O}$ distance is $2.75 \AA$, the $\mathrm{Ba}-\mathrm{Ba}$ distances of the $\mathrm{Ba}_{6}$ unit are split in a longer $(4.03 \AA)$ and a shorter $(3.70 \AA)$ one. These two different sets of distances are commonly observed in related trigonal antiprismatic $\mathrm{Ba}_{6} \mathrm{~N}$ groups and were also found in $\left(\mathrm{Ba}_{6} \mathrm{O}\right)\left(\mathrm{OsN}_{3}\right)_{2}$. They are indicative for a filled $\mathrm{Ba}_{6}$ cluster. Concerning the $\mathrm{ReN}_{3}$ building block, the Re-N distance is $1.91 \AA$, the N-Re-N angle is found to be 120 . These units are packed in $\mathrm{ABC}$ sequence with a shift of 2/3 1/3 1/3 in each step.

The Curie-Weiss law applies in the range from $\mathrm{T}=350 \mathrm{~K}$ down to $\mathrm{T}=25 \mathrm{~K}$. The Weiss constant is $\theta=-16 \mathrm{~K}$. The obtained magnetic moment $\mu=0.68$ $\mu_{\mathrm{B}}$ is small, indicating significant spin-orbit coupling.
The title compound is a semiconductor. At temperatures $\mathrm{T}<100 \mathrm{~K}$, the material is insulating with the resistivity $\rho$ exceeding $1.0^{*} 10^{6} \Omega$, while the specific conductance at RT is $\sigma=4.57 * 10^{-3} \Omega^{-1} \mathrm{~cm}^{-1}$. Applying the Arrhenius model from $\mathrm{T}=100 \mathrm{~K}$ up to $300 \mathrm{~K}$, has yielded an activation energy of $\mathrm{E}_{\mathrm{a}}=$ $0.016 \mathrm{eV}$. This low value is in accordance with the black colour of the material.

This result is suggesting that the incorporation of oxygen cannot be accounted for by discussing VEC's. We rather regard the capability of osmium and rhenium to adopt higher oxidation states the reason. This is an indispensible precondition for including additional anions, which is not fulfilled by e.g. iron.

Table 1. Crystallographic data for $\left(\mathrm{Ba}_{6} \mathrm{O}\right)\left(\mathrm{ReN}_{3}\right)_{2}$

\begin{tabular}{|c|c|}
\hline & $\left(\mathrm{Ba}_{6} \mathrm{O}\right)\left(\mathrm{ReN}_{3}\right)_{2}$ \\
\hline Space group & $R \overline{3}$ (No. 148) \\
\hline \multirow[t]{2}{*}{ Cell parameters / $\AA$} & $a=8.1178(2)$ \\
\hline & $c=17.5651(4)$ \\
\hline Cell volume / $\AA^{3}$ & $1002.43(5)$ \\
\hline $\mathrm{Z}$ & 6 \\
\hline $\mathrm{T} / \mathrm{K}$ & 300 \\
\hline Formula weight $/ \mathrm{g} / \mathrm{mol}$ & 1296.49 \\
\hline$\rho_{\text {calc }} / \mathrm{g} / \mathrm{cm}^{3}$ & 5.85 \\
\hline Radiation source $/ \lambda / \AA$ & 0.7093000 \\
\hline Capillary diameter / mm & 0.3 \\
\hline $\mathrm{R}_{\mathrm{exp}} / \%^{[\mathrm{a}]}$ & 1.44 \\
\hline $\mathrm{R}_{\mathrm{wp}} / \%^{[\mathrm{a}]}$ & 4.52 \\
\hline $\mathrm{R}_{\mathrm{p}} / \%^{[\mathrm{a}]}$ & 3.92 \\
\hline $\mathrm{R}_{\text {bragg }} / \%^{[\mathrm{a}]}$ & 1.93 \\
\hline GoF & 3.14 \\
\hline
\end{tabular}

Table 2. Atomic positions and isotropic thermal parameter of $\left(\mathrm{Ba}_{6} \mathrm{O}\right)\left(\mathrm{ReN}_{3}\right)_{2}$

\begin{tabular}{llllll}
\hline Atom & Wyck. & $\mathrm{x} / \mathrm{a}$ & $\mathrm{y} / \mathrm{b}$ & $\mathrm{z} / \mathrm{c}$ & $\mathrm{B} / \AA^{2}$ \\
\hline $\mathrm{Ba}$ & $18 \mathrm{f}$ & $0.3210(3)$ & $0.2313(2)$ & $0.4180(3)$ & $0.3(3)$ \\
$\mathrm{Re}$ & $6 \mathrm{c}$ & 0 & 0 & $0.2494(4)$ & $0.3(3)$ \\
$\mathrm{N}$ & $18 \mathrm{f}$ & $0.249(2)$ & $0.217(2)$ & $0.2494(4)$ & $0.3(3)$ \\
$\mathrm{O}$ & 3b & 0 & 0 & $1 / 2$ & $0.3(3)$ \\
\hline
\end{tabular}

Table 3. Selected bond lengths $(\AA)$ and angles $\left({ }^{\circ}\right)$ for $\left(\mathrm{Ba}_{6} \mathrm{O}\right)\left(\mathrm{ReN}_{3}\right)_{2}$

\begin{tabular}{ll}
\hline Re-N & $1.91(2)$ \\
Re-Ba & $3.485(1)$ \\
& $3.767(6)$ \\
& $3.822(6)$ \\
Ba-N & $2.76(2)$ \\
& $2.85(1)$ \\
& $3.01(1)$ \\
& $3.08(1)$ \\
& $3.20(2)$ \\
Ba-O & $2.738(3)$ \\
Ba-Ba & $3.703(6)$ \\
& $3.885(6)$ \\
& $4.033(3)$ \\
N-Os-N & 120.0 \\
\hline
\end{tabular}


We thank A. Schulz, E. Brücher and G. Siegle for measuring the Raman, the magnetic and the conductivity data. Support by the Fonds der Chemischen Industrie (FCI) and the German National Merit Foundation (scholarships for C.L. Schmidt) is gratefully acknowledged.

\section{References}

[1] C.L. Schmidt, U. Wedig, R. Dinnebier, M. Jansen, Chem. Asian J. 2008, 13, 1983-90;

[2] P. Höhn, R. Kniep, A. Rabenau, Z. Kristallogr. 1991, 196, 153-158;

[3] A. Le Bail, H. Duroy, J.L. Fourquet, Mat. Res. Bull. 1988, 23, 447-452;

[4] R.W. Cheary, A.A. Coelho, J.P. Cline, J. Res. Natl. Inst. Stand. Technol. 2005, 109, 1-25;

[5] A. Chaushli, C. Wickleder, H. Jacobs, Z. anorg. allg. Chem. 2000, 626, 892-896;

Figure 1. Rietveld plot of $\left(\mathrm{Ba}_{6} \mathrm{O}\right)\left(\mathrm{ReN}_{3}\right)_{2}$

Figure 2. The building blocks $\left(\left[\mathrm{Ba}_{6} \mathrm{O}\right]^{10+}\right.$ trigonal antiprisms and trigonal pyramidal $\mathrm{ReN}_{3}{ }^{5-}$ anions) are packed in $\mathrm{ABC}$ sequence with a shift of $2 / 31 / 3$ 1/3 each (Re dark green, Ba light green, $\mathrm{N}$ blue, $\mathrm{O}$ red). The empty trigonal antiprisms from layer to layer formed by six Ba atoms are drawn in transparent grey. 


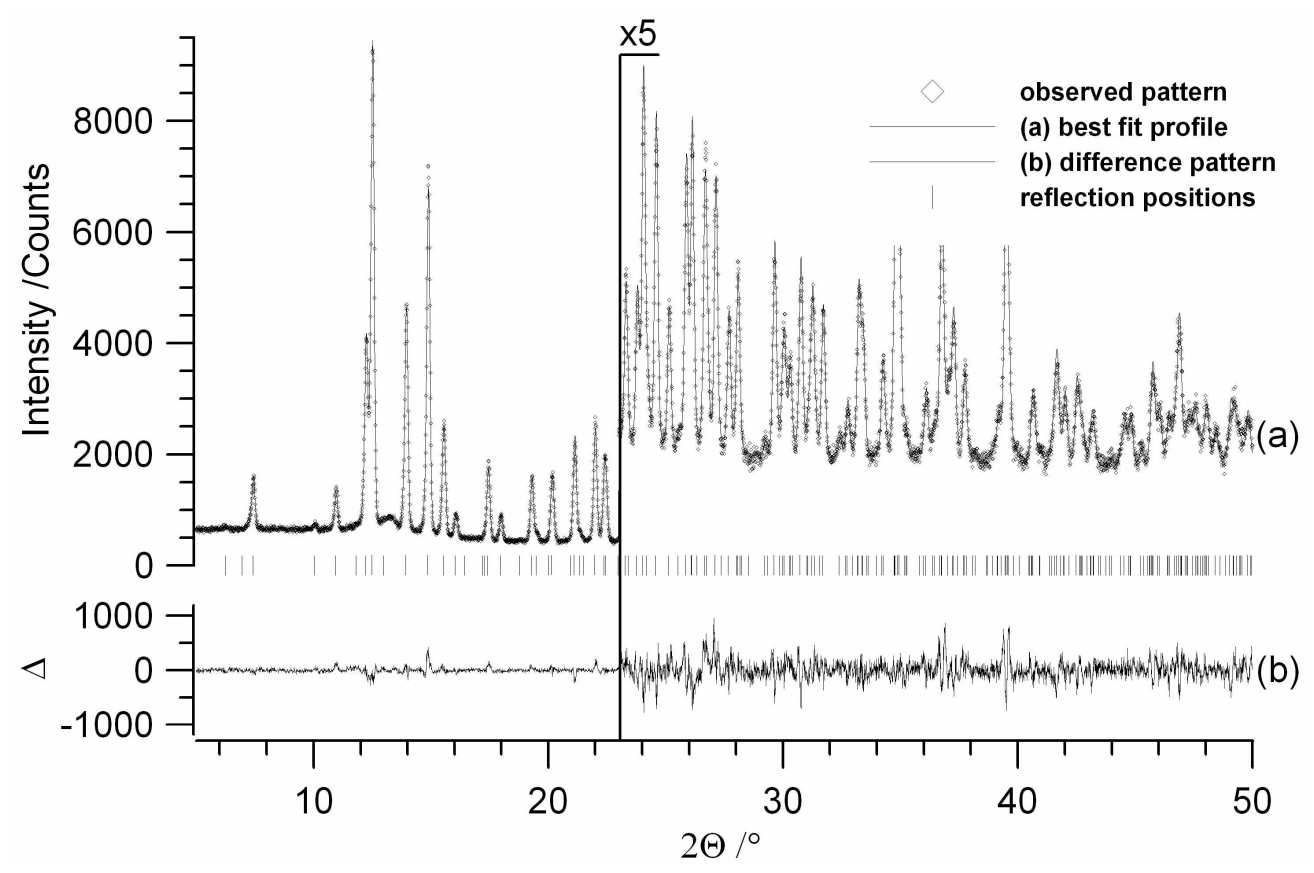

Figure 1. Rietveld plot of $\left(\mathrm{Ba}_{6} \mathrm{O}\right)\left(\mathrm{ReN}_{3}\right)_{2}$ $250 \times 164 \mathrm{~mm}$ (300 x $300 \mathrm{DPI})$ 


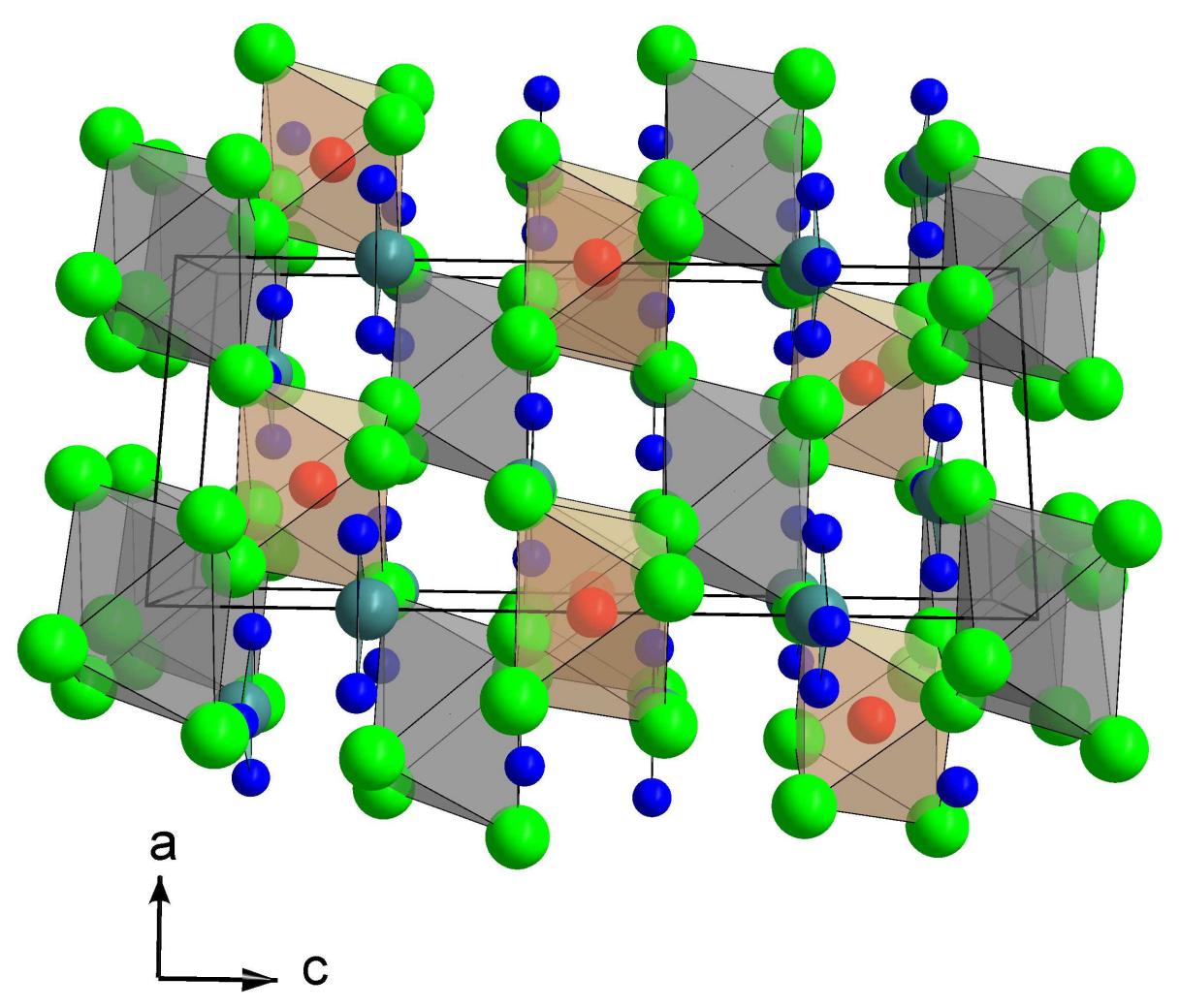

Figure 2. The building blocks ( $\left[\mathrm{Ba}_{6} \mathrm{O}\right]^{10+}$ trigonal antiprisms and trigonal pyramidal $\mathrm{ReN}_{3}{ }^{5-}$ anions) are packed in $A B C$ sequence with a shift of $2 / 31 / 31 / 3$ each (Re dark green, Ba light green, $N$ blue, $\mathrm{O}$ red). The empty trigonal antiprisms from layer to layer formed by six Ba atoms are drawn in transparent grey. $661 \times 661 \mathrm{~mm}(96 \times 96 \mathrm{DPI})$ 